\title{
You can't throw snowballs over Zoom: The challenges of service-learning reflection via online platforms
}

\author{
Sandra Smeltzer \\ Calvi Leon \\ Vanessa Sperduti \\ Western University, Canadá.
}

\begin{abstract}
COVID-19 has pervaded all aspects of higher education. Instructors are scrambling to ensure students meet predetermined learning outcomes through online communication and teaching. Students are trying to learn, collaborate, and communicate in new ways with fellow classmates and instructors. As 'traditional' service-learning activities shift to accommodate physical distancing measures and remote learning, and students wrestle with the seismic shifts in their socio-political, economic, and cultural lives, critical reflection is now more important than ever. In this article, we draw on their collective experiences to discuss the importance of establishing an open, honest, and trustworthy environment for students to thoughtfully and productively engage in domestic curricular service-learning endeavours. Specifically, we examine the challenges of facilitating service-learning reflection activities for a fourth-year undergraduate media studies course at Western University (Western), a large, research-intensive publicly funded institution in Canada. The article concludes by offering some key recommendations for how instructors can effectively engage students in critical reflection via online platforms.
\end{abstract}

\section{Keywords}

Service-learning, critical reflection, remote learning.

Fecha de recepción: 1/X/2020

Fecha de aceptación: 6/XI/2020

Smeltzer, S., Leon, C. y Sperduti, V. (2020). You can't throw snowballs over Zoom: The challenges of service-learning reflection via online platforms. RIDAS, Revista Iberoamericana de Aprendizaje Servicio, 10, 101-112. DOI10.1344/RIDAS2020.10.9 


\section{No puedes lanzar bolas de nieve sobre Zoom: una reflexión acerca de los desafíos del aprendizaje-servicio a través de plataformas online}

\section{Resumen}

El COVID-19 ha invadido todos los aspectos de la educación superior. Los docentes se esfuerzan por garantizar que los estudiantes cumplan con los resultados de aprendizaje mediante la comunicación y la enseñanza en línea. Los estudiantes están intentando aprender, colaborar y comunicarse de nuevas formas con sus compañeros y docentes. A medida que las actividades de aprendizaje-servicio "tradicionales" cambian para adaptarse a las medidas de distanciamiento físico y el aprendizaje remoto, y los estudiantes luchan con los cambios en sus vidas sociopolíticas, económicas y culturales, la reflexión crítica es ahora más importante que nunca. En este artículo, nos basamos en sus experiencias colectivas para discutir la importancia de establecer un entorno abierto, honesto y confiable para que los estudiantes se involucren de manera reflexiva y productiva en los esfuerzos de aprendizaje-servicio curricular a nivel nacional. Específicamente, examinamos los desafíos de facilitar actividades de reflexión sobre aprendizaje-servicio para un curso de estudios de medios de cuarto año de pregrado en Western University (Western), institución financiada con fondos públicos de investigación en Canadá. El artículo concluye con algunas recomendaciones clave sobre cómo los docentes pueden involucrar efectivamente a los estudiantes en la reflexión crítica a través de plataformas en línea.

\section{Palabras clave}

Aprendizaje-servicio, reflexión crítica, aprendizaje a distancia. 


\section{Introduction}

This article emerged from a conversation that initially took place in June 2020 between a faculty member (Smeltzer), a former undergraduate student who is now in graduate school (Leon), and a doctoral candidate (Sperduti) about the challenges associated with facilitating servicelearning via online platforms. The three of us have either coordinated or participated in an service-learning placement during COVID-19, are all connected to the Media \& the Public Interest program, housed in the Faculty of Information and Media Studies at Western. The curriculum in this praxisoriented, four-year program revolves around critically examining the relationship between media and social justice issues such as democracy, equity, class, race, and gender. Enrollment in the program is limited to 20 students per year with the intention of fostering a cohesive and collaborative cohort. To graduate, students are required to complete an servicelearning course in the final semester of their degree ${ }^{1}$. For this course, participants commit approximately 50 hours to working with a local community-based organization or nonprofit on a project jointly determined by both partners. Students must also meet one-on-one with the course instructor on a regular basis and bi-weekly as a group to discuss their placements,

\footnotetext{
${ }^{1}$ As of 2020, Smeltzer works with 76 different organizations to coordinate service-learning placements in London, a mid-sized Canadian city with a population of $\sim 400,000$ citizens.
}

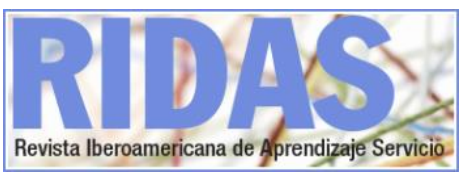

share their experiences, engage with relevant theory, and participate in myriad reflection activities. Based on the successful completion of their placement, demonstrable in-class engagement, and the submission of a mid-term report and theoretically informed final paper, the course is graded as a Pass, Fail, or, in exceptional circumstances, a Pass with Distinction.

Our shared service-learning course was slated for the winter semester -January to May 2020- with Smeltzer as the instructor, Leon as a student, and Sperduti as a Research Assistant. On March 12th, all courses at our institution were moved online because of COVID-19. Faculty members, nonacademic staff, students, and community partners scrambled to complete service-learning projects virtually to finish out the academic semester. Instructors shifted to virtual classrooms and managed pedagogical responsibilities alongside community partner relationships. Students moved off campus and/or out of the city to continue their studies in remote locales. Organizations hosting service-learning students adjusted project activities and modes of delivery to achieve mutually agreed upon objectives within the semester time frame.

While service-learning instructors aim to prepare students for 'the good, the bad, and the ugly' aspects of this form of community-oriented, hands-on pedagogy (Smeltzer, 2020), there was no way of foreseeing that students would finish their final university semester in the midst of a pandemic. As a result of school closures and the implementation of social distancing 
measures, students either transitioned their service-learning work online (e.g., delivering presentations via Zoom and completing research projects remotely) or prematurely concluded their placement. Fortunately, most students in our program were able to complete their original service-learning project with relatively minor modifications. However, something very important fell through the cracks for all students in this course - critical reflection.

\section{Critical reflection in times of pandemic}

As has been well-established, in-depth, critical reflection is the cornerstone of service-learning and must be intertwined throughout the pedagogical process (Ash \& Clayton, 2009; Hickson, 2011; Mitchell et al., 2015; Sanders, Van Oss, \& McGeary, 2016; Tiessen, 2018). By students taking ownership of their learning, they are better able to glean insights into the relationship between their academic curriculum and their practical experiences working within the community. Critical reflection also empowers students to better understand their own positionalities, subjectivities, and biases, and nurtures a heightened awareness of their personal self-efficacy (Finley \& Reason, 2016; Pirbhai-Illich, 2013).

These reflection activities often take place in class, allowing space for students to share their experiences with one another, to offer peer-to-peer support, and to better understand systemic forms of marginalization and inequality. Group settings also provide participants an opportunity to envisage the work of other organizations and to broaden their understanding of the people they serve. Notwithstanding these hoped-for benefits, shared reflection experiences may also prove stressful for many students who want to "appear competent and gain the respect of others" and, as a result, could be "unwilling to share deficits and perceived inadequacies" (Priesmeyer, Mudge, \& Ward, 2016, p.60). Collective reflection activities must therefore be conducted in ways that advance an ethos that is "accepting of mistakes, perceived inadequacies or flaws and supportive and encouraging of the personal and professional growth of participants" (Priesmeyer, Mudge, \& Ward, 2016, p.60). This kind of empathetic approach is especially important when an service-learning experience is not an entirely positive one. While we hope service-learning placements to be personally, academically, and professionally beneficial for students, we recommend against telling only 'success stories' of community engagement. Indeed, it is important to also acknowledge challenges and unfavourable (even adverse) outcomes of this pedagogical practice. As Schutter (2018) contends, "the continuous sharing of positive stories and problems with pleasant endings seems to reduce the meaning and gravity of our service. If positivity is the ethos of service-learners, students lose the opportunity to express the entirety of their experience" (p.9). Hence, the objective of our Media \& the Public Interest service-learning course is to provide students with the reflection tools they need to productively work through a 
range of thoughts and emotions stemming from their community-based encounters.

Given the momentous personal and societal shifts currently taking place due to COVID-19, this kind of critical reflection has become increasingly important to students' general wellbeing (Rapanta et al., 2020). However, the expeditious move to remote learning has impacted our typical reflection processes. Our institution, for instance, has adopted the use of Zoom, Google Teams, and VoiceThread for most online classes. But do these multimedia platforms, even with careful and creative planning of guided activities, afford the same opportunities for students to engage, reflect, and collaborate as would be the case if they were in person? We address this question through a discussion of throwing snowballs, a class favourite reflection exercise designed to capture students' wide-ranging feelings about their service-learning experience before, during, and after their respective placements.

\section{Throwing snowballs}

As Canadians, we are accustomed to snowball fights during winter months, but these classroom 'snowball' fights are slightly different than the reader might expect. During this tripartite reflection exercise, students are first given (recycled) pieces of paper and asked to anonymously write down their ideas, thoughts, feelings, and experiences in response to a series of questions posed by the instructor. Such questions might include: 'What have you found the most surprising thus far in your placement?'; 'Have you experienced something that has helped you grow as a person?'; 'Have you encountered any challenges and, if so, how have you addressed them?'; and 'By the end of the semester, what do you hope to have gained from this experience?' Once students have written their responses to a given question, they scrunch the pieces of paper into 'snowballs' and throw them across the room. Once the 'fight' has finished, students pick up a snowball and, when prompted by the instructor, read out loud the written response. This reflection exercise, which is both embodied and anonymous, allows participants to communicate their concerns, their challenges and successes, what they have learned, and how they feel about their servicelearning experience (SALTISE, 2020).

During the second step of this reflection process, students are asked if they wish to share their feelings and opinions regarding the snowball comments they heard in class. They then brainstorm ideas as a class about how to foster positive service-learning experiences and productively address problematic ones. Students often find that they have more in common than they realized, even though they are completing placements at different organizations and engaging in diverse types of work for communities with various needs. Importantly, the instructor also hears students' concerns, opinions, and feelings. Therefore, after the snowball fight concludes, instructors can engage in the third part of the process by following up with students both 
individually and as a group to discuss what transpired in class and beyond (Eyler, Giles, \& Schmiede, 1996).

\subsection{Why snowball fights work: openness and honesty}

The snowball exercise works because it encourages students to shift their mindsets away from 'products produced' or 'hours spent' to focus instead on the impact of their servicelearning placements on themselves, on their host organization, and on the community/ies they support (Clifford, 2017; Schutter, 2018). Service-learning should provide students space to learn, grow, contribute, and even falter. The anonymous aspect of this reflection exercise gives them an opportunity to express a range of emotions without fear of recrimination or judgement. Students may feel hesitant to share negative or challenging aspects of their experiences, especially if their peers only have positive things to say about their placement. Critical reflection can thus help to normalize the difficult or challenging aspects of service-learning, which in turn can alleviate students' discomfort or emotional distress (Hatchers \& Bringle, 1997; Liddell, Hubbard \& Werner, 2000). The activity is particularly useful for students who are less comfortable speaking in group settings or sharing their experiences as openly with others.

Speaking from my (Leon) experience participating in this reflection exercise, I felt a sense of relief in listening to my peers express concerns similar to mine about their placements. For example, one of my classmates shared in their 'snowball' that they felt the burden of being given significant responsibility at their placement, which were feelings similar to my own. Conversely, many of my peers wrote that they were worried about not having enough responsibility or autonomy at their organization. I found that the openness and honesty we embraced in our class was made possible by the anonymity of this particular exercise, combined with the camaraderie we built as a group sharing the same physical space.

While we prefer such embodied educational experiences, it is currently not possible for students to be present in a physical classroom. With physical distancing restrictions in place, students have also had to follow the guidelines of their community partners who, again, for the most part, have switched gears to deliver programs and services online. For some students in our program, this transition led to them feeling disconnected and less engaged with their host organization and the citizens it supports. However, other students commented in their final papers that they enjoyed working with community partners in an online setting and gained greater insight into different aspects of the inner workings of a non-profit. Further, numerous students said they acquired skills that will be beneficial to their lives post-graduation, while others mentioned that they thought they played an important role in helping their respective organization to weather the COVID-19 storm. In fact, students in our program often expressed pride in being able to utilize their communication and critical thinking skills to support community partners seeking solutions to problems posed by

Smeltzer, S., Leon, C. y Sperduti, V. (2020). You can't throw snowballs over Zoom: The challenges of service-learning reflection via online platforms. RIDAS, Revista Iberoamericana de Aprendizaje Servicio, 10, 101-112. DOI10.1344/RIDAS2020.10.9 
the pandemic. Whether students were given the responsibility of helping to write grant proposals, creating a social media strategy, or conducting policyoriented research, they gained greater appreciation for the work charities and non-profits dedicate to supporting their communities.

\section{COVID-19 and Zoom}

The shift to virtual forms of critical reflection has not been as problematic for us, the co-authors, as it may be for other service-learning participants for two reasons. First, our personalities allow us to be relatively open about our feelings, a trait that lends itself to wanting to engage in reflection activities both on and offline. Second, prior to the current pandemic, the three of us had already developed an inperson relationship based on considerable face-to-face contact in previous courses and research activities. Given that we have nurtured these relationships through mutual trust and respect, we have continued to engage in critical reflection even if the content is uncomfortable and even if it transpires via a technology platform. However, many students do not share this kind of relationship with either their peers or their instructors and, as a result, may not want to divulge apprehensions, express concerns, or tout successes for myriad personal and academic reasons.

As the instructor (Smeltzer), the primary concern I have heard over the years from students is that they feel like they are not being 'used' to their optimal potential during their servicelearning placement. Some also comment that, at times, they are frustrated by having to engage in tedious work (even though tedium is often part and parcel of operating in the non-profit sector) (Seitz, 2018).

Although many students are comfortable expressing these kinds of apprehensions and discontent, others are not. I worry that when reflection exercises are conducted through online mediums such as Zoom, students will be even more reluctant to relay challenges they are experiencing or to 'complain' about their placement. They may be especially reluctant to do so if they know their host organization is struggling financially as a result of the pandemic, combined with greater community needs and increased pressure on citizens' mental health (Strub, 2020). I am also concerned that going online for reflection exercises can remove some of the vulnerability and transparency between instructors and students that is necessary for the latter to work through uncomfortable or challenging experiences. Further, preCOVID, our program's service-learning classrooms were designed for students to face one another in a circle to facilitate greater participation, peer-topeer engagement, and a palpable sense of camaraderie. Without this embodied time together, I have found that there is a (virtual) communication barrier between participants. From the instructor's point-of-view, 'reading' one room can be difficult; reading 20 'rooms' online for emotional cues is significantly more challenging.

Additionally, traditional academic power dynamics are often amplified in Zoom. At our institution, it is mandatory to 
either use the 'waiting room' feature on this software platform, whereby instructors individually allow students into the online forum, or students must enter a specific passcode each time they participate in a class. Students are usually asked to keep their microphones on mute at all times, unless speaking or told otherwise. To ask a question or intervene, they either physically put up their hand on camera or use the 'raise-hand' feature under the 'participants' section. In some cases, depending on the instructor's teaching style, students are added to a 'speaker's list' and wait their turn to participate in a conversation. From Sperduti's perspective, I have found that this structure makes it challenging for both students and instructors to engage in natural and interactive discussions, as the process is mediated by technology. The absence of social cues that would normally be present in the physical classroom also makes it difficult for students to read the emotional state of their peers, to know how best to engage in conversations about difficult topics or respond to issues raised, or to gauge social interactions. As well, without the contextual information afforded by face-to-face interaction, it can be hard for students to build a kind of trustbased relationship with their instructor necessary for engaging in authentic self-reflection.

As the discussion above intimates, we cannot translate "an exact replica of an in-person course to online format during COVID-19... as it neglects to consider... personal, psychological, and logistical concerns of students and professors" (Christian, McCarty, \& Brown, 2020, p.2). Nevertheless, we believe that students can still benefit tremendously from understanding the unique challenges faced by non-profit organizations during a pandemic. Certainly, from Leon's and Sperduti's perspective, critical reflection plays a central role in this process by allowing students to better understand and contextualize their experiences in the current terrain marred by COVID- 19 .

\section{Recommendations}

As the pandemic continues for the foreseeable future, we offer some recommendations to support students' commitment to critical reflection during what we expect will be anomalous service-learning experiences.

First, we recommend that institutions of higher education provide servicelearning instructors with appropriate support to facilitate technologically mediated reflection, recognizing that there is an important distinction between online learning and emergency remote teaching (Hodges, Moore, Lockee, Trust \& Bond, 2020; Rapanta et al., 2020). Given the multifaceted and flexible nature of service-learning, instructors already use various online means of communication between themselves, students, community partners, and other academic and nonacademic staff. Hence, attention should not be focused on restructuring servicelearning curricula but rather on clearly articulating expected learning outcomes and emphasizing the importance of critical reflection even if it looks different than in the past (Finley, 2017). To this end, we suggest an 
online alternative to the more traditional snowball fights described above: instructors can use the breakout room feature (or its equivalent) on communication platforms such as Zoom or Microsoft Teams to organize small groups of three or four students, providing prompts to facilitate reflective discussions between the group's participants. Students are encouraged to collectively develop solutions to problems and discuss methods of cultivating positive experiences. Similar to the snowball activity, students can brainstorm and exchange ideas, and individuals who are less comfortable speaking in front of their classmates have an opportunity to interact in smaller group-based discussions that best simulate face-to-face interactions. Instructors can ask that one person from each group share highlights and key challenges expressed in the breakout room when the whole class reconvenes. Although the instructor is unable to hear what students are saying in each of the 'rooms,' they can glean a sense of how students feel by listening to comments made during the broader discussion that ensues.

Second, we recommend proactively advocating to departmental, Faculty, and institutional administrators that critical reflection is paramount to effective and ethical forms of servicelearning and that it requires a significant outlay of labour. Facilitating time-intensive group and individualized reflection exercises, especially during a pandemic, also requires considerable emotional care work. Therefore, service-learning instructors must have the support(s) they need to care for their own well-being and to help students find and make use of available mental health resources. As Martin, Lecrom \& Lassiter (2017) argue, "university administrators must demonstrate that they support servicelearning, through actions rather than just words" (p. 51). To this end, in addition to recognizing the emotional toll of facilitating service-learning, provision of requisite human and financial resources can have a demonstrably positive impact on instructors' personal and professional lives.

Third, we recommend incorporating peer-to-peer mentoring between incoming and former service-learning students. In our Media \& the Public Interest program, for example, we created a 'buddy system' whereby students entering into the servicelearning course are given the contact information of graduates ${ }^{2}$ who previously completed a placement with the same community partner and can reflect upon the positive and challenging aspects of their own experiences they encountered. In doing so, these graduates help alleviate students' anxiety about the process and can aid in managing expectations regarding their placements.

\section{Concluding Thoughts}

Notwithstanding the value of mediated

\footnotetext{
2 Once marks have been submitted at end of term (to mitigate against students feeling obligated to participate), students who have completed the MPI course are asked by the instructor (Smeltzer) if they wish to provide their contact information to future cohorts of service-learning students in the program.
} 
reflection exercises, we cannot be "distracted by the technology and by a concern with identifying the most appropriate technological solution, or blend of online platforms" (Bryson \& Andres, 2020, p.4). In a similar vein, we advise against the allure of technological determinism and perfunctory forms of reflection. Rather, as Christian, McCarty, and Brown (2020) elucidate, and we concur, students need time "to reflect on their lived experiences during the COVID-19 pandemic" (p.10). We thus strongly recommend that instructors actively carve out this space, however and wherever it transpires, and foster the importance of in-depth reflection, which takes both time and mindfulness.

Though it may be awhile before anyone has an indoor 'snowball fight', we can create a comparable experience of value for students in the interim. Instructors can continue to work with their institutions, students, and community partners to explore new ways of engaging in reflection activities and building meaningful relationships that will endure beyond the pandemic. Interactions certainly look much different now than before but connecting with one another remains critically important to our collective well-being.

\section{References}

Ash, S. L., \& Clayton, P. H. (2009). Generating, deepening, and documenting learning: The power of critical reflection in applied learning. Journal of Applied Learning in Higher Education, 1, 25-48.
Bryson, J. R., \& Andres, L. (2020). Covid-19 and rapid adoption and improvisation of online teaching: curating resources for extensive versus intensive online learning experiences. Journal of Geography in Higher Education, 1-16.

Christian, D. D., McCarty, D. L., \& Brown, C. L. (2020). Experiential education during the COVID-19 pandemic: A reflective process. Journal of Constructivist Psychology, 1-14.

Clifford, J. (2017). Talking about service-learning: Product or process? Reciprocity or solidarity? Journal of Higher Education Outreach and Engagement, 21(4), 1-13.

Eyler, J., Giles, D.E. \& Schmiede, A. (1996). A practitioner's guide to reflection in service-learning. Nashville: Vanderbilt University Press.

Finley, A. (2017). Delivering on the promise of civic learning: Toward more meaningful and intentional

assessment. In C. Dolgon, T.D Mitchell \& T.K. Eatman (Eds.), The Cambridge handbook of service learning and community engagement (pp. 183-192). Cambridge University Press.

Finley, A., \& Reason, R. D. (2016). Community-engaged signature work: How a high-impact practice may support student well-being. Diversity and Democracy, 19(4), 1-5.

Hickson, H. (2011). Critical reflection: Reflecting on learning to be reflective. Reflective practice, $12(6)$, 829-839. 
Hodges, C., Moore, S., Lockee, B., Trust, T., \& Bond, A. (2020, 27 March). The difference between emergency remote teaching and online learning. Educause Review. Retrieved from: https://er.educause.edu/articles/ 2020/3/the-difference-betweenemergency-remote-teaching-andonline-learning

Liddell, D., Hubbard, S., \& Werner, R. (2000). Developing interventions that focus on learning. New Directions for Student Services, 2000(90), 21-33. doi: $10.1002 /$ ss.9002

Martin, T. R., Lecrom, C. W., \& Lassiter, J. W. (2017). Hearts on our sleeves: Emotions experienced by servicelearning faculty. The International Journal of Research on ServiceLearning and Community Engagement, 5(1).

Mitchell, T. D., Richard, F. D., Battistoni, R. M., Rost-Banik, C., Netz, R., \& Zakoske, C. (2015). Reflective Practice That Persists: Connections between Reflection in Service- Learning Programs and in Current Life. Michigan Journal of Community Service Learning, 21(2), 49-63.

Pirbhai-Illich, F. (2013). Crossing borders: At the nexus of critical service learning, literacy, and social justice. Waikato Journal of Education, 18(2), 79-96.

Priesmeyer, H. R., Mudge, S. D., \& Ward, S. G. (2016). Emotional responses to service learning: An exploratory study. Journal of Learning in Higher Education, 12(2), 55-61.
Rapanta, C., Botturi, L., Goodyear, P., Guàrdia, L., \& Koole, M. (2020). Online university teaching during and after the Covid-19 crisis: Refocusing teacher presence and learning activity. Postdigital Science and Education, 1-23.

SALTISE. (2020, February 13). Snowball. Retrieved from: https://www.saltise.ca/strategy/snowba II/

Sanders, M. J., Van Oss, T., \& McGeary, S. (2016). Analyzing reflections in service learning to promote personal growth and community selfefficacy. Journal of Experiential Education, 39(1), 73-88. doi: $10.1177 / 1053825915608872$

Schutter, C. M. (2018). Moving beyond great expectations: Expressing discontinuity in institutionalized servicelearning. VA Engage Journal, 6(1), 5.

Seitz, D. K. (2018). "It's not about you": Disappointment as queer pedagogy in community-engaged service-learning. Journal of Homosexuality, 67(3), 305-314.

Smeltzer, S. (2020). Wearing multiple reflexive hats: The ethical complexities of media-oriented community engaged learning. In In S. Jeppesen \& P. Sartoretto (Eds.), Media Activist Research Ethics (pp. 131-154). Palgrave Macmillan, Cham.

Strub, C. (2020, May 25). Survey: 44\% of Nonprofits Anticipate Further Staff Cuts Due To Coronovirus. Forbes. Retrieved from: https://www.forbes.com/sites/chrisstru 
b/2020/05/25/layoffs/\#75a1c93c50d4

Tiessen, R. (2018). Improving student reflection in experiential learning reports in post-secondary institutions. Journal of Education and Learning, 7(3), 1-10. 